\title{
KAJIAN KINERJA SIKLON PEMBERSIH DAN PENGARUHNYA TERHADAP KONSENTRASI GAS-GAS HASIL GASIFIKASI TANDAN KOSONG KELAPA SAWIT
}

\section{Performance Analysis of Purifying Cyclone and Its Impact to Gas Concentration Produced by Gasification of Oil Palm Empty Fruit Bunches}

\author{
Joni1 $^{12 *}$, Renaldi Sebayang, Johana Marpaung ${ }^{2}$, Radite Praeko Agus Setiawan ${ }^{2}$, \\ Armansyah Halomoan Tambunan ${ }^{2}$, Kiman Siregar ${ }^{3}$ \\ ${ }^{1}$ Jurusan Teknik Mesin - Fakultas Teknik -Universitas Cenderawasih \\ Jl. Kamp Wolker - Waena - Jayapura 99351 \\ ${ }^{2}$ Departemen Teknik Mesin dan Biosistem - Fakultas Teknologi Pertanian - Institut Pertanian Bogor \\ Kampus Dramaga - Bogor 16681 \\ ${ }^{3}$ Departemen Teknik Pertanian - Fakultas Pertanian - Universitas Syiah Kuala \\ Jl. Teuku Nyak Arief No. 441 - Kopelma Darussalam - Banda Aceh 23111 \\ *Penulis Korespondensi, email: me.uncen@gmail.com
}

Disubmit: 27 Juli 2020 Direvisi: 20 November 2020 Diterima: 26 Desember 2020

\begin{abstract}
ABSTRAK
Pembersihan partikel-partikel pengotor dari gas-gas hasil gasifikasi tandan kosong kelapa sawit merupakan salah satu proses penting yang harus dilakukan untuk mendapatkan gas pembawa energi dengan kemurnian yang lebih baik. Pemisahan partikel-partikel tersebut dari umumnya dilakukan dengan menggunakan siklon. Konstruksi dan kondisi operasi siklon, seperti suhu gas yang masuk, berperan penting dalam menentukan kinerja pemisahan partikel dari gas tersebut. Penelitian ini bertujuan untuk mengkaji pengaruh perubahan suhu gas terhadap kinerja siklon dalam memisahkan partikulat dan tar dari gas-gas hasil gasifikasi tandan kosong kelapa sawit. Hasil kajian menunjukkan bahwa peningkatan suhu gas yang masuk ke siklon mampu memisahkan partikel berukuran 5-6 $\mu \mathrm{m}$ di kisaran suhu $200-300{ }^{\circ} \mathrm{C}$ pada efisiensi minimum $50 \%$. Hasil perhitungan efisiensi pengumpulan rata-rata mencapai $98,23 \%$, sedangkan hasil pengukuran adalah $85,56 \%$. Hasil perhitungan dan ekperimen terhadap tekanan jatuh pada siklon, masing-masing, adalah 100,11 dan $87 \mathrm{mmH}_{2} \mathrm{O}$, berada pada kisaran standar tekanan jatuh yang disarankan. Efisiensi dan tekanan jatuh yang diperoleh menunjukkan bahwa siklon dapat bekerja dengan baik. Hasil kajian menunjukkan bahwa siklon sebaiknya digunakan pada tahap awal dari proses pemisah partikel dari gas hasil gasifikasi, pada saat suhu gas masih tinggi
\end{abstract}

Kata kunci : Efisiensi Pengumpulan; Pengurangan Diameter; Penurunan Tekanan; Suhu Gas; Tar

\section{ABSTRACT}

Gas purification is one of a very crucial process required to be performed in order to obtain a better quality of gasses produced by grasification of oil palm empty fruit bunches. A cyclone is usually used in the purification process to separate particles and tarss from the gas. Particle separating performance of a cyclone is affected by its construction and operating conditions, such as temperature of the entering gas. The objectives of this study is to examine the effect of the entering gas temperature to the cyclone performance in separating particulates and tar from gases produced by gasification of oil palm empty fruit bunch. The results shows that the cyclone was capable in separating particles with size of 5-6 $\mu \mathrm{m}$ at entering gas temperature range of 200$300{ }^{\circ} \mathrm{C}$, at a minimum efficiency of $50 \%$. The calculated average collection efficiency was $98.23 \%$ while the experimental results were $84.56 \%$. Calculation and experimental data on pressure drop within the cylone was 100.11 and $97.0 \mathrm{mmH}_{2} \mathrm{O}$, respectively, and fall within the required standard pressure drop. The collection efficiency and pressure drop indicated that the cyclone performed well. The study also suggests that cyclone is best to be used at the first row of the purification system for gases produced by gasification of empty fruit bunch since the temperature is still high enough.

Keywords : Collection Efficiency; Diameter Cut Size; Pressures Drop; Temperature of Gas; Tar 
Jurnal Teknologi Pertanian Vol. 21 No. 3 [Desember 2020] 211-218

Kajian Kinerja Siklon Pembersih dan Pengaruhnya terhadap Konsentrasi Gas-gas Hasil Gasifikasi [Joni dkk]

\section{PENDAHULUAN}

Pemanfaatan biomassa untuk energi mendapat perhatian besar karena mempunyai potensi besar, bersifat terbarukan, dan ramah terhadap lingkungan. Salah satu potensi yang sangat besar di Indonesia adalah tandan kosong kelapa sawit (TKKS). TKKS merupakan limbah pengolahan kelapa sawit yang dapat mencapai 20-23\%, disamping serat, cangkang, dan limbah cair pabrik kelapa sawit (Palm oil mill effluent; POME). Konversi biomassa TKKS ke energi dapat dilakukan dengan berbagai teknologi konversi, termasuk gasifikasi. Gasifikasi biomassa dilakukan untuk menghasilkan gas-gas producer (producer gas), tetapi juga menghasilkan sejumlah partikel yang tidak diinginkan dan bercampur dengan gas-gas tersebut. Partikel-partikel yang terkandung dalam gas produk umumnya berupa rantai karbon (arang, jelaga, dan tar) dan senyawa anorganik, seperti abu dan partikel yang terkondensasi dari senyawa gas. Partikelpartikel tersebut umumnya dapat menyebabkan endapan, erosi dan korosi pada peralatan instalasi serta pada mesin yang menggunakan gas-gas tersebut. Pembersihan partikel-partikel pengotor tersebut merupakan salah satu proses penting yang harus dilakukan untuk mendapatkan syngas dengan mutu yang baik untuk digunakan sebagai energi. Pemisahan partikel-partikel tersebut dari gas-gas hasil gasifikasi umumnya dilakukan dengan menggunakan siklon.

Siklon adalah jenis pemisah inersia yang bekerja secara mekanis dengan memanfaatkan gaya sentrifugal yang dihasilkan oleh aliran gas. Siklon pemisah terdiri dari dua tipe atau jenis yang diklasifikasikan berdasarkan pergerakkan fluida yang masuk, yaitu tipe radial dan aksial. Pada tipe radial, gas masuk ke dalam ruang siklon dengan bantuan blower, menyentuh dinding dan melakukan gerakan melingkar, sedangkan pada tipe aksial, siklon menggunakan baling-baling (vane) yang berputar membawa gas ke dalam ruang siklon membentuk gerakan aksial. Kedua tipe ini menghasilkan gaya sentrifugal pada putaran tinggi, melemparkan partikel ke dinding silinder dan kerucut, kemudian meluncur ke bawah menuju ruang pengumpulan. Gas yang telah bersih akan bergerak balik, naik ke atas membentuk spiral yang lebih kecil menuju saluran pencari pusaran untuk keluar dari ruang siklon.

Siklon biasanya digunakan untuk menghilangkan partikel berukuran $10 \mu \mathrm{m}$ dan lebih besar. Siklon dengan efisiensi tinggi mampu menghilangkan partikel dengan ukuran hingga $5 \mu \mathrm{m}$. Siklon volume tinggi menyebabkan penurunan efisiensi penggumpulan, sehingga umumnya digunakan sebagai pembersih awal untuk menghilangkan partikel yang lebih besar sebelum gas melewati peralatan siklon lainnya. Siklon dapat dioptimalkan untuk mendapatkan efisiensi pengumpulan yang tinggi dengan menggunakan diameter kecil, silinder panjang, dan kecepatan saluran masuk tinggi (Miller, 2017). Faktor yang mempengaruhi kinerja siklon, yaitu dimensi siklon pemisah (Hsu et al., 2014), sifat fisik gas, dan kondisi operasi (Gimbun et al., 2004). Sifat fisik tersebut adalah densitas dan viskositas gas. Kondisi operasi meliputi suhu, kecepatan masuk gas dan geometri siklon. Suhu gas yang masuk ke peralatan perlu mendapat perhatian karena penurunan suhu dapat menyebabkan penggumpalan senyawa yang terkondensasi sepanjang saluran pipa dan peralatan lainnya. Oleh karena itu, diperlukan simulasi dan analisis kinerja siklon dalam memisahkan partikulat dan tar dari gas-gas hasil gasifikasi berdasarkan sifat fisik dan kondisi operasional siklon tersebut. Penelitian ini bertujuan untuk mengkaji pengaruh perubahan suhu gas terhadap kinerja siklon dalam memisahkan partikulat dan tar dari gas-gas hasil gasifikasi tandan kosong kelapa sawit.

\section{METODE}

Penelitian ini merupakan kajian analitik yang selanjutnya diverifikasi dengan hasil eksperimen. Alur penelitian ditunjukkan pada Gambar 1. Komposisi senyawa tar dalam gas ditentukan berdasarkan analisis laboratorium menggunakan Pyro-GCMS tipe PY-2020iS dan GCMS-QP2010 pada Laboratorium $\mathrm{BPPHH}$, Bogor. Konsentrasi gas mampu bakar setelah pembersihan, berupa $\mathrm{CO}, \mathrm{CO}_{2}, \mathrm{H}_{2}$, dan $\mathrm{CH}_{4}$, diukur dengan gas analyzer GASBOARD-3100P.

Parameter yang digunakan untuk menganalisis kinerja siklon berupa data hasil pengukuran pada eksperimen, antara lain dimensi konstruksi siklon yang ditunjukkan pada Gambar 2a; komposisi gas dan konsentrasinya; densitas partikel; laju aliran; suhu; viskositas, densitas gas; dan densitas partikel. Analisis dilakukan dengan pendekatan model empiris yang dikembangkan oleh 
Iozia dan Leith (1990), alur analisis kinerja siklon pemisah ditunjukkan pada Gambar 1. Penelitian Zhao (2012) dan Zhao et al. (2020) menyebutkan model tersebut lebih baik dan banyak digunakan untuk menduga efisiensi siklon dibandingkan beberapa model yang telah ada berdasarkan pengujian dan perbandingan teoritis yang dilakukan.

Persamaan 1 dan 2, masing-masing digunakan untuk menentukan debit aliran gas $\left(Q ; \mathrm{m}^{3} / \mathrm{s}\right)$, dan densitas gas $\left(\rho ; \mathrm{kg} / \mathrm{m}^{3}\right)$, di mana $A$ adalah luas penampang saluran pipa (m), BM adalah berat molekul senyawa (kg/ $\mathrm{mol}) ; \mathrm{v}_{\text {gas }}$ adalah kecepatan aliran gas. Pengurangan diameter (diameter cut size) ditentukan dengan Persamaan 7, dimana $v_{t \max }$ adalah kecepatan maksimum gas saat terangkat menuju lubang pencari vorteks (m/s) yang dapat dihitung dengan Persamaan 8. Dalam hal ini, N adalah jumlah siklon yang digunakan secara paralel, $\rho_{\mathrm{p}}$ adalah densitas (m/s); T adalah suhu gas (K); $\mathrm{R}$ adalah konstanta gas umum (8314,3 J/mol K); P adalah tekanan (Pa).

Viskositas gas campuran dapat dihitung dengan menggunakan persamaan empiris yang dikembangkan oleh Lee et al. (1996) dan telah diverifikasi hubungan korelasinya oleh Jeje dan Mattar, (2004); Yang et al. (2017), seperti Persamaan 3. Dalam hal ini $\mathrm{K}, \mathrm{X}, \mathrm{Y}$ adalah koefisien korelasi yang masing-masing dapat ditentukan dengan Persamaan 4,5 , dan 6. Parameter partikel $\left(\mathrm{kg} / \mathrm{m}^{3}\right)$,

$\mathrm{Q}=\mathrm{V} \times \mathrm{A}$

$\rho_{g a s}=\frac{P \times B M_{g a s}}{R \times T}$

$\mu_{g}=10^{-4} \mathrm{~K} \exp \left[X\left(\rho_{g}\right)^{Y}\right]$

$K=\frac{(9,379+0,01 \mathrm{BM})(1,8 \mathrm{~T})^{1,5}}{209,2+19,26 \mathrm{BM}+1,8 \mathrm{~T}}$

$X=3,488+\frac{986,4}{1,8 \mathrm{~T}}+0,01009 \mathrm{BM}$

$\mathrm{Y}=2,447-0,2224 \mathrm{X}$

$$
\mathrm{d}_{50}=\sqrt{\frac{9 \mu(Q / N)}{\pi\left(\rho_{p}-\rho_{\text {gas }}\right) \mathrm{z}_{\mathrm{c}} \mathrm{v}_{\mathrm{t} \max }^{2}}}
$$

$\mathrm{v}_{t \max }=6,1 \mathrm{v}\left(\frac{\pi \mathrm{ab}}{\mathrm{D}^{2}}\right)^{0,61}\left(\frac{\mathrm{D}_{e}}{\mathrm{D}}\right)^{-0,74}\left(\frac{\mathrm{H}}{\mathrm{D}}\right)^{-0,33}$

$\mathrm{v}=\frac{Q / N}{\pi \mathrm{ab}}$

dan $z_{\mathrm{c}}$ adalah panjang lintasan natural yang dilalui gas dalam siklon (m). Gambar 2 menunjukkan dimensi siklon yang diperlukan dalam perhitungan.

Salah satu metode untuk memperkirakan tekanan jatuh (pressure drop) didasarkan pada kecepatan head dan dimensi pada sisi masuk dan keluar peralatan siklon, seperti ditunjukkan pada Persamaan 14. $\Delta \mathrm{H}$ adalah parameter non-dimensional yang bergantung pada geometri siklon. Ramachandran et al. (1991) melakukan pengujian pada 98 konfigurasi siklon untuk menentukan korelasi terbaik secara statistik dalam memprediksi $\Delta \mathrm{H}$ seperti pada Persamaan 14 . Efisiensi pengumpulan dapat dihitung dengan menggunakan Persamaan 15-16.

Validasi hasil analisis dilakukan terhadap data eksperimen menggunakan reaktor gasifikasi biomassa jenis unggun tetap aliran ke bawah berkapasitas $20 \mathrm{~kg}$ untuk TKKS. Gas hasil gasifikasi dialirkan ke siklon dengan blower berkapasitas $690 \mathrm{~m}^{3}$ /jam dan putaran 2800 rpm (Gambar 2b). Pengukuran suhu dilakukan dengan menggunakan termokopel tipe $\mathrm{K}$ dan tekanan statis pada sisi masuk, keluar dan bagian ruang dalam siklon dilakukan dengan manometer air (tipe U). Sampel tar dikumpulkan pada 2 buah botol yang berisi cairan isopropanol $100 \mathrm{ml}$ dan ditempatkan pada wadah yang berisi butiran es untuk mencegah penguapan

$$
\begin{aligned}
& \mathrm{d}_{c}=0,47 \mathrm{D}\left(\frac{\pi \mathrm{ab}}{\mathrm{D}^{2}}\right)^{-0,25}\left(\frac{\mathrm{D}_{e}}{\mathrm{D}}\right)^{1,4} \\
& \mathrm{z}_{c}=(\mathrm{H}-\mathrm{S})-\left[\frac{\mathrm{H}-\mathrm{h}}{(\mathrm{D} / \mathrm{B})-1}\right]\left[\left(\mathrm{d}_{c} / \mathrm{B}\right)-1\right] . \\
& \mathrm{z}_{\mathrm{c}}=(\mathrm{H}-\mathrm{S})
\end{aligned}
$$

$\Delta \mathrm{H}=20\left(\frac{\pi \mathrm{ab}}{\mathrm{D}_{e}^{2}}\right)\left[\frac{\mathrm{S} / \mathrm{D}}{(\mathrm{H} / \mathrm{D})(\mathrm{h} / \mathrm{D})(\mathrm{B} / \mathrm{D})}\right]^{1 / 3}$.

$\eta_{i}=\frac{1}{1+\left(\frac{\mathrm{d}_{50}}{\mathrm{~d}_{\mathrm{pi}}}\right)^{\beta}}$

$\ln \beta=0,62-0,87 \ln \left(\frac{\mathrm{d}_{50}}{1000}\right)+5,21 \ln \left(\frac{\pi \mathrm{ab}}{\mathrm{D}^{2}}\right)+1,05\left[\ln \left(\frac{\pi \mathrm{ab}}{\mathrm{D}^{2}}\right)\right]^{2}$. 
pelarut dan memudahkan gas produk masuk ke dalam perangkap tersebut. Pada bagian keluar botol perangkap dipasang rotameter untuk mengatur laju aliran gas $0,51 /$ menit dan pompa vakum sebagai penyedotnya. Tar dan partikel yang terperangkap dalam botol berisi cairan isopropanol dipanaskan pada suhu $85^{\circ} \mathrm{C}$ untuk menguapkan cairan pelarut, sehingga yang tersisa hanya tar.

\section{HASIL DAN PEMBAHASAN}

\section{Karakteristik Gas Hasil Gasifikasi}

Tabel 1 menunjukkan karakteristik senyawa tar yang dihasilkan melalui proses pirolisis tandan kosong kelapa sawit (TKS) dan dianalisis menggunakan Pyro-GCMS tipe PY-2020iS dan GCMS-QP2010. Gas yang diperoleh pada suhu $400{ }^{\circ} \mathrm{C}$ terdiri atas enam senyawa dalam fase gas dengan konsentrasi yang berbeda, yaitu furan $(0,01 \%)$, guaiacol $(0,06 \%)$ phenol $(0,07 \%)$, syringol $(0,10 \%)$, 4-ethylsyringol $(0,02 \%)$, dan mixed oxygenates $(0,07 \%)$. Komposisi tersebut digunakan untuk menghitung densitas gas hasil gasifikasi. Perhitungan pada suhu yang berbeda $\left(200,300,400,500\right.$ dan $\left.600{ }^{\circ} \mathrm{C}\right)$ menghasilkan masa jenis senyawa yang masing-masing bernilai 1,002; 0,827; 0,704; 0,613; dan 0,543 $\mathrm{kg} / \mathrm{m}^{3}$. Nilai densitas gas sangat bergantung pada suhu, dimana peningkatan suhu akan menurunkan nilai densitas.

Selanjutnya, nilai densitas yang diperoleh digunakan untuk menghitung viskositas dinamik gas pada berbagai suhu. Hasil perhitungan ditunjukkan pada Gambar 3, dimana pada suhu $200,300,400,500$, dan $600^{\circ} \mathrm{C}$, viskositas dinamik gas masing-masing adalah 0,00022; 0,00032; 0,00046; 0,00061; dan 0,00076 $\mathrm{Ns} / \mathrm{m}^{2}$. Viskositas dinamik gas mengalami peningkatan seiring dengan peningkatan suhu. Hal ini menunjukkan perilaku ikatan molekul gas tersebut, yaitu pada suhu rendah terjadi ikatan yang lebih erat dibandingkan dengan pada suhu tinggi.

\section{Kinerja Siklon Pemisah}

Salah satu indikator kinerja siklon adalah diameter cut size $\left(\mathrm{d}_{50}\right)$, yaitu diameter partikel yang dapat dipisahkan dengan efisiensi minimum 50\%. Diameter pengurangan ( $d i-$ ameter cut size) dihitung berdasarkan kecepatan maksimum gas memasuki siklon dan dimensi siklon yang digunakan. Gambar 4 menunjukkan hasil perhitungan diameter particle cut size 50 pada berbagai suhu. Pada suhu $200{ }^{\circ} \mathrm{C}$, diameter partikel yang dapat dipisahkan dengan efisiensi minimum 50\% adalah 5,98 $\mu \mathrm{m}$. Peningkatan suhu gas yang masuk ke siklon menyebabkan penurunan kemampuan untuk menghilangkan partikel yang lebih kecil, sehingga hanya partikel berukuran besar yang dapat dipisahkan. Hal ini sesuai dengan pengaruh viskositas, yang menurun dengan peningkatan suhu, sebagaimana dijelaskan sebelumnya. Berdasarkan Gambar 4, partikel yang dapat dipisahkan pada suhu $600^{\circ} \mathrm{C}$ dengan efisiensi minimum $50 \%$ adalah yang berukuran sebesar $11,22 \mu \mathrm{m}$.

Fenomena yang sama juga dijelaskan oleh Parker et al. (1981), yang melakukan eksperimen menggunakan udara pada suhu 700 ${ }^{\circ} \mathrm{C}$, dan menyimpulkan bahwa efisiensi pengumpulan menurun secara dramatis saat terjadinya peningkatan suhu. Efek meningkatnya suhu gas terhadap nilai efisiensi total siklon, masing-masing adalah 99,17\% ( $\left.\mathrm{T}=200{ }^{\circ} \mathrm{C}\right)$; 98,85\% ( $\left.\mathrm{T}=300{ }^{\circ} \mathrm{C}\right) ; 98,34 \%\left(\mathrm{~T}=400{ }^{\circ} \mathrm{C}\right) ; 97,73 \%$ $\left(\mathrm{T}=500{ }^{\circ} \mathrm{C}\right)$; dan $97,05 \%\left(\mathrm{~T}=600{ }^{\circ} \mathrm{C}\right)$. Batasan nilai efisiensi pengumpulan partikel siklon pemisah penggunaan secara umum adalah 7090\% dan pengurangan emisi pada gas berkisar antara $80-99 \%$ (EPA, 2003).

Diameter cut size berkaitan langsung dengan efisiensi pengumpulan oleh siklon. Gambar 5 menunjukkan hubungan antara diameter partikel dengan efisiensi pengumpulan partikel pada berbagai suhu gas yang masuk ke siklon. Partikel dengan ukuran yang lebih besar lebih mudah terperangkap dalam penampungan siklon, sehingga menghasilkan efisiensi pengumpulan yang tinggi. Gas yang terkontaminasi dengan partikulat masuk ke siklon dan berputar melewati dinding utama sebelum memasuki pusaran dalam dan bergerak ke atas menuju pintu keluar siklon. Hasil analisis menunjukkan bahwa siklon, dengan dimensi seperti ditunjukkan sebelumnya, mampu memisahkan partikel berukuran 5-6 $\mu \mathrm{m}$ dari gas hasil gasifikasi pada kisaran suhu $200-300^{\circ} \mathrm{C}$, dengan efisiensi minimum $50 \%$.

Hasil pengukuran terhadap berat pengotor gas (tar, partikulat, dan uap air) yang dilakukan pada eksperimen gasifikasi TKKS dengan waktu pengoperasian selama 7 jam, diperoleh pengotor sebanyak $416 \mathrm{~g}$ dan pada penampungan sebelum dan setelah melewati siklon $63 \mathrm{~g}$. Data tersebut menunjukkan bahwa efisiensi pengumpulan aktual yang mampu dilakukan 
Jurnal Teknologi Pertanian Vol. 21 No. 3 [Desember 2020] 211-218 Kajian Kinerja Siklon Pembersih dan Pengaruhnya terhadap Konsentrasi Gas-gas Hasil Gasifikasi [Joni dkk]

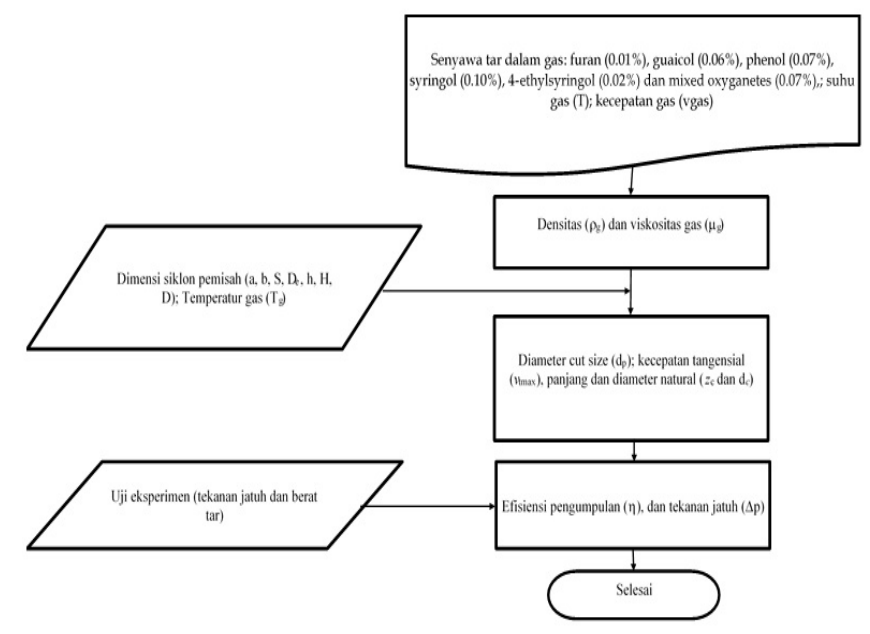

Gambar 1. Alur proses kajian kinerja siklon berdasarkan karakteristik gas

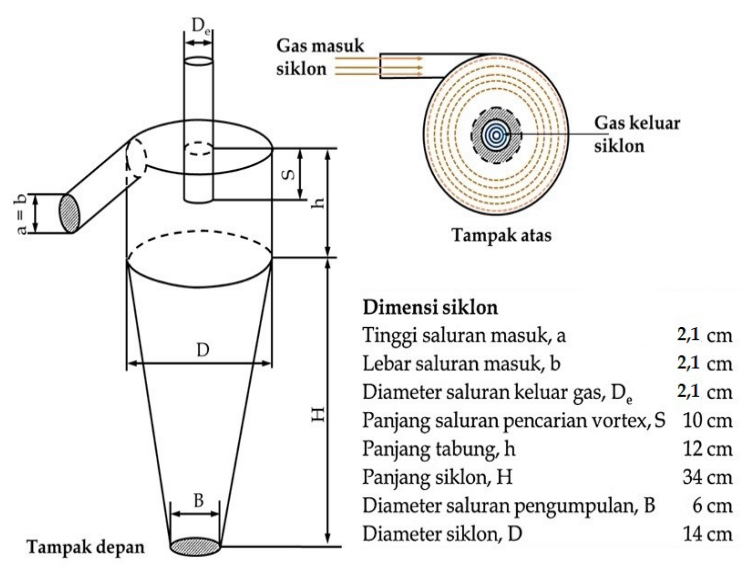

(a)

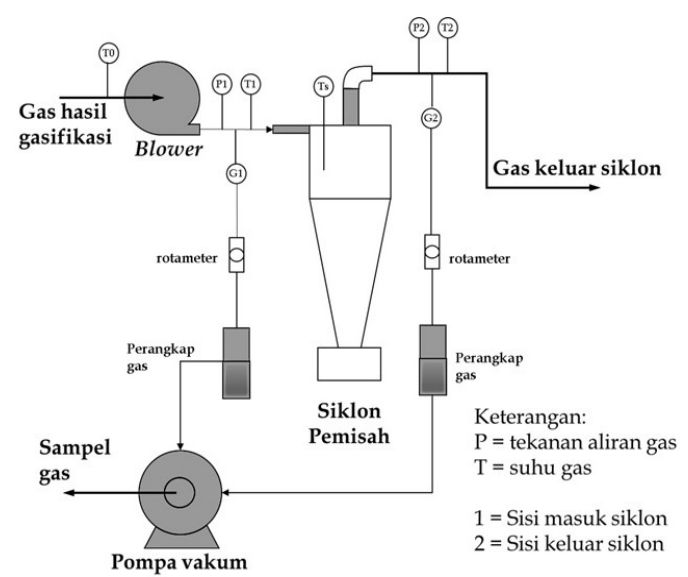

(b)

Gambar 2. (a) Konstruksi dan dimensi siklon, dan (b) set-up pengujian siklon yang digunakan

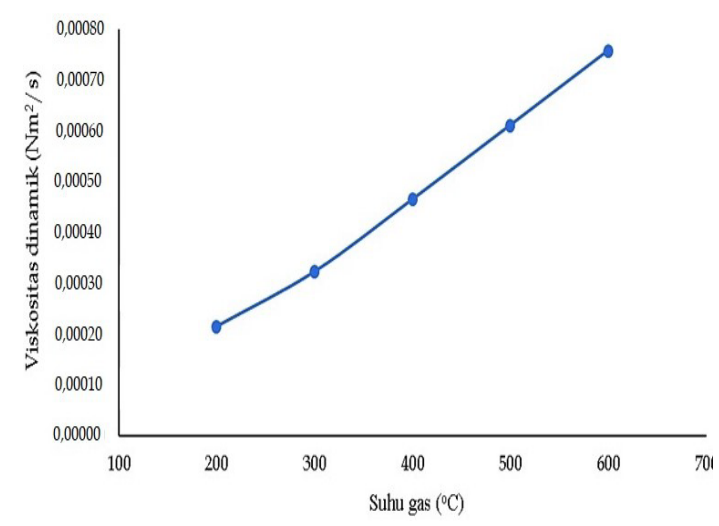

Gambar 3. Hubungan suhu dengan viskositas gas hasil gasifikasi

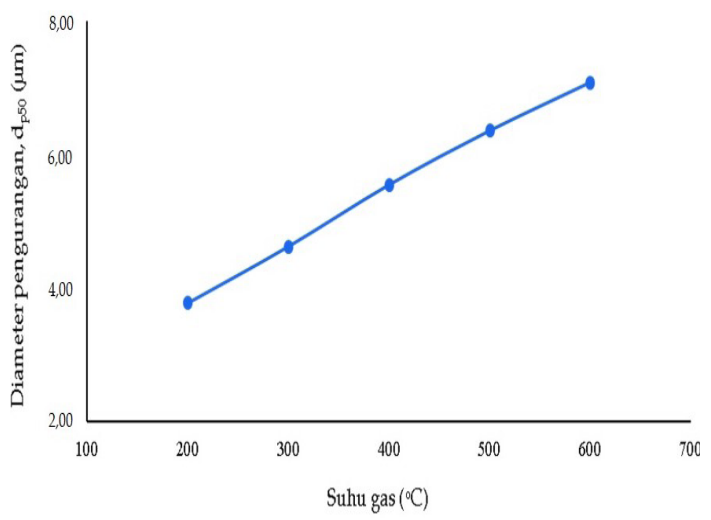

Gambar 4. Hubungan suhu dengan diameter pengurangan $\left(\mathrm{dp}_{50}\right)$ 
Jurnal Teknologi Pertanian Vol. 21 No. 3 [Desember 2020] 211-218

Kajian Kinerja Siklon Pembersih dan Pengaruhnya terhadap Konsentrasi Gas-gas Hasil Gasifikasi [Joni dkk]

Tabel 1. Kelompok senyawa organik individu menjadi senyawa tar yang dihasilkan dari pirolisis sampel TKKS*)

\begin{tabular}{|c|c|c|c|c|c|c|}
\hline $\begin{array}{c}\text { Kelas } \\
\text { senyawa tar }\end{array}$ & $\begin{array}{c}\text { Bentuk } \\
\text { senyawa }\end{array}$ & $\begin{array}{c}\text { Kons. } \\
(\%)\end{array}$ & Nama & $\begin{array}{c}\text { Rumus } \\
\text { kimia }\end{array}$ & $\begin{array}{c}\text { MW } \\
(\mathrm{g} / \mathrm{mol})\end{array}$ & CAS \\
\hline \multirow{6}{*}{$\begin{array}{l}\text { Kelompok } \\
\text { senyawa tar } \\
\text { utama } \\
\text { (Kelas 2) }\end{array}$} & Furan & 0,01 & $\begin{array}{l}\text { 2-furanmethanol (CAS) } \\
\text { furfuryl alcohol }\end{array}$ & $\mathrm{C}_{5} \mathrm{H}_{6} \mathrm{O}_{2}$ & 98 & $98-00-0$ \\
\hline & Guaiacol & 0,06 & $\begin{array}{l}\text { phenol, 2-me- } \\
\text { thoxy-(CAS) guaiacol }\end{array}$ & $\mathrm{C}_{7} \mathrm{H}_{8} \mathrm{O}_{2}$ & 124 & $90-05-1$ \\
\hline & Phenol & 0,07 & $\begin{array}{l}\text { phenol, 4-ethyl-2-me- } \\
\text { thoxy- }\end{array}$ & $\mathrm{C}_{9} \mathrm{H}_{12} \mathrm{O}_{2}$ & 152 & 2785-89-9 \\
\hline & syringol & 0,10 & $\begin{array}{l}\text { phenol, 2,6-dimethoxy- } \\
\text { (CAS) 2,6-dimethoxy- } \\
\text { phenol }\end{array}$ & $\mathrm{C}_{8} \mathrm{H}_{10} \mathrm{O}_{3}$ & 154 & $91-10-1$ \\
\hline & $\begin{array}{l}\text { 4-ethylsy- } \\
\text { ringol }\end{array}$ & 0,02 & $\begin{array}{l}\text { phenol, 4-ethyl-2-me- } \\
\text { thoxy- (CAS) 2,6-dime- } \\
\text { thoxyphenol }\end{array}$ & $\mathrm{C}_{10} \mathrm{H}_{14} \mathrm{O}_{3}$ & 182 & $14059-92-8$ \\
\hline & $\begin{array}{c}\text { Mixed } \\
\text { oxygenates }\end{array}$ & 0,07 & $\begin{array}{l}\text { 2-propanone, 1-hy- } \\
\text { droxy-(CAS) acetol }\end{array}$ & $\mathrm{C}_{3} \mathrm{H}_{6} \mathrm{O}_{2}$ & 74 & 116-09-6 \\
\hline
\end{tabular}

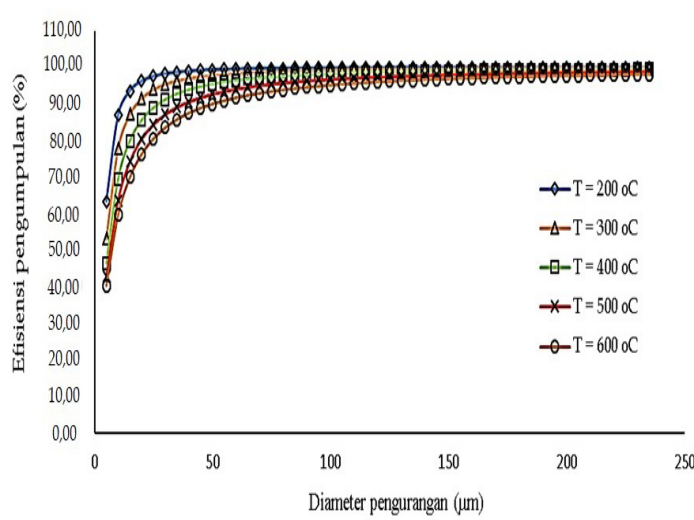

Gambar 5. Hubungan diameter partikel terhadap efisiensi pengumpulan

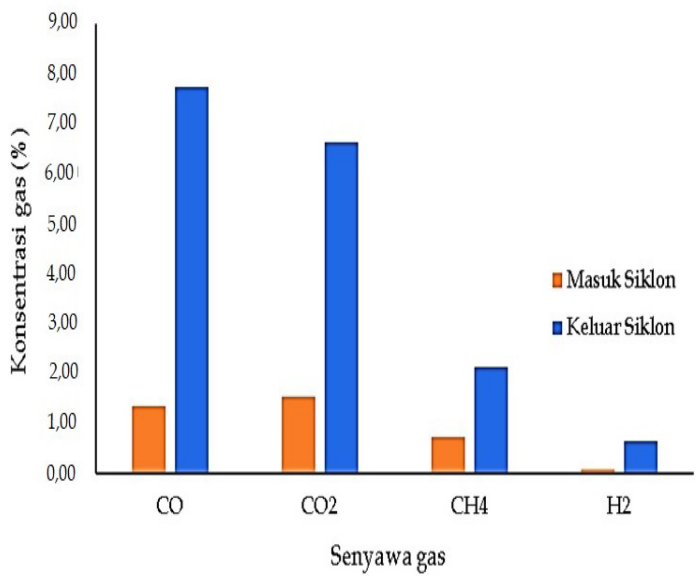

Gambar 7. Perbandingan konsentrasi gas-gas yang melewati peralatan siklon

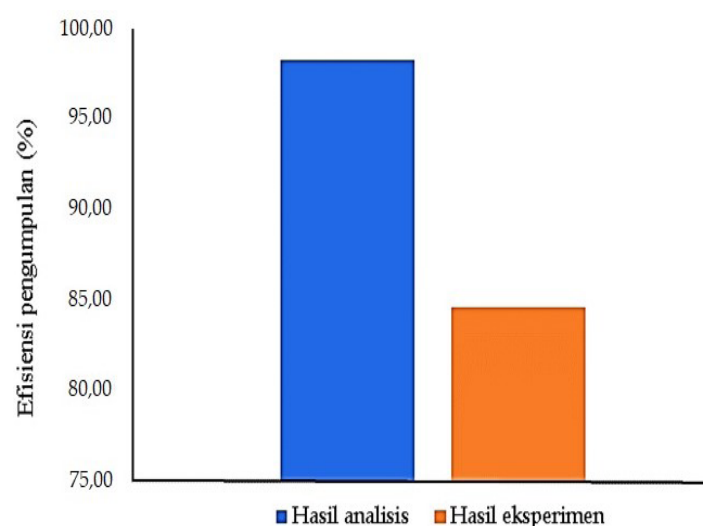

Gambar 6. Perbandingan efisiensi pengumpulan analisa dan eksperimen

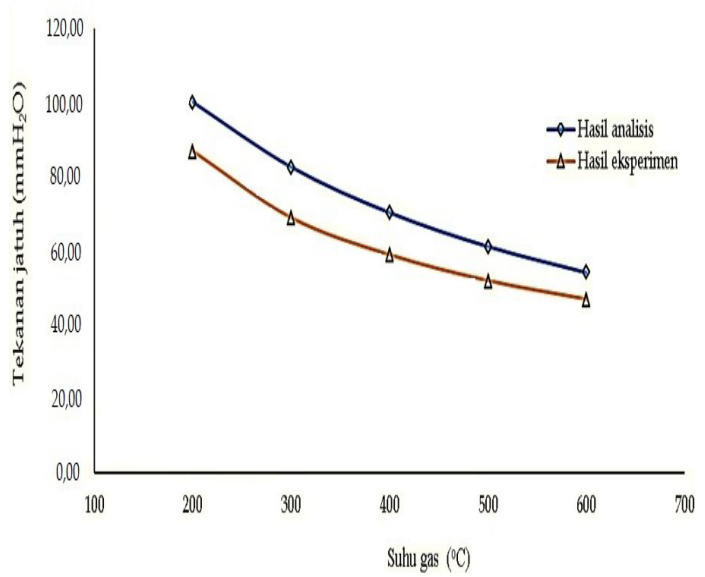

Gambar 8. Hubungan suhu gas terhadap tekanan jatuh 
oleh siklon untuk membersihkan gas adalah $84,56 \%$. Hasil perhitungan menunjukkan bahwa efisiensi pengumpulan dengan menggunakan bahan dan dimensi siklon yang sama memberikan efisiensi pengumpulan ratarata sebesar 98,23\% (Gambar 6). Peningkatan efisiensi pemisahan berbanding lurus dengan densitas partikel. Hal ini karena peningkatan perbedaan kerapatan partikel dan gas menghasilkan gaya sentrifugal yang lebih tinggi pada pemisah siklon (Gawali dan Bhambere, 2015). Gaya sentrifugal pada partikel dengan densitas tinggi akan terlempar ke dinding dan kehilangan energi hingga jatuh ke ruang pengumpulan (Marinuc dan Rus, 2011). Pada pemisah siklon, partikel berukuran besar biasanya terpisah seluruhnya dibanding dengan partikel yang lebih kecil dari diameter kritis pemisah siklon.

Berdasarkan penjelasan sebelumnya, penggunaan siklon pemisah berdasarkan standar penggunaan siklon EPA (2019), hasil analisis dan eksperimen yang dilakukan telah memenuhi syarat batasan nilai efisiensi dari siklon. Konstruksi siklon yang digunakan temasuk dalam kategori efisiensi tinggi 80-90\%. Ikatan gas yang lebih erat akan menyebabkan partikel berukuran kecil yang terdapat pada gas lebih mudah dilepaskan dan dihempaskan pada dinding siklon menuju ruang penampungan sebelum dikeluarkan dari siklon. Pada suhu tinggi, partikel berukuran kecil akan lebih mudah untuk terbawa bersama gas dan sulit untuk dipisahkan dari aliran gas. Gimbun et al. (2004), kepadatan partikel udara yang besar menyebabkan gaya sentrifugal yang bekerja pada partikel bertambah, dan gaya sentrifugal tersebut berdampak pada efisiensi pemisahan yang lebih tinggi dari siklon. Terlepasnya partikel-partikel kecil ini dapat menyebabkan terjadinya penggendapan pada pipa instalasi yang digunakan dan menurunkan kualitas gas-gas mampu bakar yang dihasilkan.

Gambar 7 menunjukkan perbandingan hasil pengukuran konsentrasi gas hasil gasifikasi sebelum dan sesudah siklon pemisah, yaitu berupa gas $\mathrm{CO}, \mathrm{CO}_{2^{\prime}} \mathrm{H}_{2^{\prime}} \mathrm{CH}_{4^{\prime}}$ dan $\mathrm{C}_{\mathrm{n}} \mathrm{H}_{\mathrm{m}}$. Gas diperoleh dengan bantuan pompa vakum kecepatan hisap 0,5 1/menit yang terlebih dulu dialirkan melalui larutan isopropanol untuk mengikat senyawa tar dan partikulat yang terbawa bersama gas producer. Gas tersebut ditampung pada wadah kantong kedap udara, dan diuji pada gas analyzer untuk mendapatkan nilai konsentrasinya.
Sebelum memasuki siklon, gas mengandung banyak partikulat serta uap air dan tar pada fase gas. Keberadaan pengotor tersebut menyebabkan gas-gas producer yang terukur lebih rendah dibandingkan dengan setelah melewati siklon. Hal ini menunjukkan bahwa siklon bekerja dengan baik dalam memisahkan zat-zat pengotor yang terdapat pada gas-gas hasil gasifikasi.

Indikator lain yang diperlukan dalam menentukan kinerja siklon adalah tekanan jatuh yang terjadi pada siklon tersebut. Tekanan jatuh yang besar akan menyebabkan kebutuhan daya yang besar untuk memindahkan gas sepanjang siklon. Gambar 8 menunjukkan perbandingan tekanan jatuh hasil perhitungan dengan pengukuran yang terjadi pada siklon. Hasil pengukuran menunjukkan tekanan jatuh yang lebih rendah tetapi mempunyai kecenderungan yang sama pada suhu yang berbeda. Berkurangnya tekanan jatuh pada suhu gas yang lebih tinggi disebabkan oleh penurunan densitas gas dan peningkatan viskositas gas (Gimbun et al., 2005). Hasil penelitian ini sebanding dengan hasil yang diperoleh oleh Gimbun et al. (2005), yang melakukan pengujian kinerja siklon secara simulasi dan eksperimen. Hasil pengukuran menunjukkan bahwa tekanan jatuh pada siklon yang digunakan adalah $87 \mathrm{mmH}_{2} \mathrm{O}$ pada suhu gas $200^{\circ} \mathrm{C}$, sedangkan hasil perhitungan pada suhu yang sama adalah 101,11 $\mathrm{mmH}_{2} \mathrm{O}$. Nilai tersebut memenuhi standar tekanan jatuh yang diperlukan, yaitu 50,8-254 $\mathrm{mmH}_{2} \mathrm{O}$.

\section{SIMPULAN}

Peralatan siklon pemisah yang digunakan untuk pembersihan gas-gas hasil gasifikasi mampu menghilangkan partikel dengan baik dan memenuhi standar efisiensi pengumpulan yang disyaratkan, yaitu 70-99\% dari hasil simulasi dan ekperimen sebesar $98,23 \%$ dan $84,56 \%$. Perhitungan dan ekperimen masing-masing menghasilkan tekanan jatuh sebesar 100,11 dan $87 \mathrm{mmH}_{2} \mathrm{O}$, serta memenuhi standar tekanan jatuh yang disarankan. Terpenuhinya batasan efisiensi dan tekanan jatuh, konstruksi peralatan siklon yang digunakan mampu untuk diterapkan sebagai peralatan pembersih gas-gas hasil gasifikasi dari pengotor berupa tar, partikulat dan uap air. Hasil kajian juga menunjukkan bahwa siklon sebaiknya digunakan sebagai pemisah 
Jurnal Teknologi Pertanian Vol. 21 No. 3 [Desember 2020] 211-218

Kajian Kinerja Siklon Pembersih dan Pengaruhnya terhadap Konsentrasi Gas-gas Hasil Gasifikasi [Joni dkk]

awal untuk menghilangkan partikel dalam gas hasil gasifikasi pada saat suhu gas masih tinggi.

\section{UCAPAN TERIMA KASIH}

Penelitian ini didukung oleh Departemen Keuangan Republik Indonesia dengan Dana Abadi Indonesia untuk Pendidikan (LPDP - Lembaga Pengembangan Dana Pendidikan) dan Kementerian Riset, Teknologi, dan Pendidikan Tinggi Republik Indonesia.

\section{DAFTAR PUSTAKA}

EPA. 2019. Air pollution control technology fact sheet. Dilihat 1 Juli 2019. <https://www3. epa.gov/ttn/catc/dir1/ff-pulse.pdf>

Gawali, S, -S., Bhambere, M, -B., 2015. Effect of design and operating parameters on the performance of cyclone separator - A review. International Journal of Mechanical Engineering and Robotics Research. 4(1), 244-248. http://www. ijmerr.com/show-126-217-1.html

Gimbun, -J., Choong, T, S, -Y., Razi, A, -F., Ghuah, T, -G., 2004. Prediction of the effect of dimension, particle density, temperature, and inlet velocity on cyclone collection efficiency. Jurnal Teknologi Universiti Teknologi Malaysia. 40, 37-50. https://doi.org/10.11113/ jt.v40.421

Gimbun, J., Chuah, TG., Razi, AF., Choong, TSY. 2005. The influence pf temperature and inlet velocity on cyclone pressure drop: a CFD study. Chemical Engineering and Processing: Process Intensification. 44(1), 7-12. https://doi. org/10.1016/j.cep.2004.03.005

Hsu, C, -W., Huang, S, -H., Lin, C, -W., Hsiao, T, -C., Lin, W, -Y., Chen, C, -C., 2014. An experimental study on performance improvement of the stairmang cyclone design. Aerosol and Air Quality Research. 14(3), 1003-1016. https:/ / doi. org/10.4209/aaqr.2013.04.0129

Iozia, D, -L., Leith, -D., 1990. The logistic function dan cyclone fractional efficiency. Aerosol Science and Technology. 12(3), 598-606. https://doi. org/10.1080/02786829008959373
Jeje, -O., Mattar, -L. 2004. Comparison of correlations for viscosity of sour natural gas. Petroleum Society of Canada. https://doi.org/10.2118/2004-214

Joni., Tambunan, A, -H., Setiawan, R, P, -A., Siregar, -K., 2019. Study on characteristics of oil palm empty fruit bunch to predict condensation temperature of tar from its pyrolysis gas. International Journal of Oil Palm. 2(3), 120-130. http://ijop.id/index.php/ijop/article/download/42/32

Lee, A, -L., Gonzalez, M, -H., Eakin, B, -E., 1966. The viscosity of natural gases. Journal of Petroleum Technology. 18(8), 997-1000. https://doi. org/10.2118/1340-PA

Marinuc, -M., Rus, -F., 2011. The effect of particle size and input velocity on cyclone separation process. Bulletin of the Transilvania University of Brasov. 4(2), 117-122. http://webbut.unitbv.ro/ BU2011/Series\% 20II/ BULETIN\% 20 II/Marinuc_M.pdf

Miller, BG. 2017. Clean Coal Engineering Technology. Elsevier, London

Parker, -R., Jain, -R., Calvert, -S., Abbot, -J., 1981. Particle collection in cyclone at high temperature and high pressure. Environmental Science and Technology. 15(4), 451- 458. https://doi. org/10.1021/es00086a010

Ramachandran, -G., Leith, -D., Dirgo, -J., Feldman, -H., 1991. Cyclone optimization based on a new empirical model for pressure drop. Aerosol Science and Technology. 15(2), 135-148. https:/ / doi. org/10.1080/02786829108959520

Yang, -X., Zhang, -S., Zhu, -W., 2017. A new model for the accurate calculation of natural gas viscosity. Natural Gas Industry B. 4(2), 100-105. https://doi. org/10.1016/j.ngib.2017.07.011

Zhao, B. 2012. Prediction of gas-particle separation efficiency for cyclones: A timeof-flight model. Separation and Purification Technology. 85, 171-177. https:// doi.org/10.1016/j.seppur.2011.10.006

Zhao, -B., Wang, -D., Su, -Y., Wang, H, -L., 2020. Gas-particle cyclonic separation dynamics: Modeling and characterization. Separation \& Purification Reviews. 49(2), 1-31. https:// doi.org/10.1080/1 5422119.2018.1528278 